一論 文—

（日本化学会誌，1992，（1），p.63～67）

(C) 1992 The Chemical Society of Japan

\title{
合成ゼオライト存在下でのモノテルペン炭化水素類の 水による水和反応12)
}

(1991 年 8 月 7 日受理)

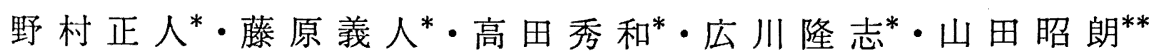

固体酸触媒としてのゼオラィトは, 従来の無定形シリカ・アルミナあるいは活性白土触媒よりも多く の反応に扔いて高い活性を示す一方，ゼオライトが持っている固体酸性は，プロトンあるいは金属カチ オンと共存するカチオンの量と種類によっても影響を受けることが明らかにされている。そこで，著者 らもこのよらなゼオライトが持っている酸を利用し，モノテルペン炭化水素類である $d-$ リネン $[1]$, 2 -ピネン〔2]，2(10)ーピネン〔3]，カンフェン〔4]抽よびトリシクレン〔5]の水の存在下に拉け る水和反応について検討した。

その結果，〔1]の場合にはフェリェライト形ゼオラィトである HSZ-710 HOA 合成ゼオライトを用 いた反応に执いて， $d$-カルボン〔8] を主成分として得ることができた。また，〔2]の場合において も HSZ-710 HOA 合成ゼオライトを用いた反応において $\alpha$-テルピネオール〔7〕を主成分として得 ることがでさた。一方，〔3]の場合には天然ゼオライトである $2020 \mathrm{AH}$ (モルデナイト型) ゼオライ 卜を用いた反応に执いて，trans-ベルベノール〔11]を最高 $71 \%$ の生成比で得ることができた。つ ぎに，〔4〕および〔5]の場合には助触媒として塩化亜鉛あるいは水酸化アルミニウムを添加し， Y 型ゼオライトに属する HSZ-330 HUA 合成ゼオライトあるいはモルデナイト型ゼオライトに属する HSZ-620 HOA 合成ゼオライトを用いた反応に括いて，イソボルネオール〔16〕と $n$-ボルネオール 〔17〕の 2 成分の GLC 組成比が $2: 3$ あるいは 1:1 の割合になることがわかった。このように，基 質の構造によりそれぞれのゼオライトの組合せを考慮することにより，生成物の選択性に大きな相違が 認められるなどの新しい知見を見いだすことができた。

\section{1 緒言}

近年，ゼオライトは固体酸にかぎらずイオン交換することによ り種々の優れた触媒機能を有する高機能材料として広い分野で利 用されるよらになっている3゙ 6)。

そこで，著者らは，既報》に引き続き， 従来から数多くの方法 による酸化反応8199あるいは水和反応10111)が行われているモノテル ペン炭化水素である $d-$ リモネン [1],2-ピネン〔2]，2(10)-ピ ネン〔3]，カンフェン〔4]抽よ゙トリシクレン［5]につい て, A 型, $\mathrm{X}$ 型, $\mathrm{Y}$ 型, クリノプチロライト型およびモルデナイ 卜型ゼオライトに属するそれぞれのゼオライトの固体酸性を利用 し, 水の存在下に上る水和反応を行い, 反応の選択性を追求する とともに，水がゼオライトに及ぼす影響についても愉討したので

* 近畿大学工学部工業化学科, 729-17 東広島市高屋 5 めの 辺 1 番

** 近畿大学九州工学部工業化学科, 820 飯塚市柏/森 11-6

1）この報文を“テルペン類の合成ゼオライトを触媒とする反 応(第 9 報)”とする.

2）前報(第 8 報)，野村正人，藤原義人，日化，1989，1160.

3) P. B. Weisz, V. J. Frilitte, J. Phys. Chem., 64, 382 (1960).
報告する。

\section{2 実験}

\section{1 試料の調製}

リモネン〔1]，2-ピネン[2]，2(10)ーピネン〔3]抽よびカ ンフェン〔4]；市眅品（安原ケミカル株式会社製）[1]，〔2]， 〔3〕および〔4]をそれぞれ $10 \%$ 水酸化ナトリウム水溶液で洗 浄したのち, 減圧下に精留し得たもので, いずれも GLC (PEG $\left[600010 \%, \phi 3 \mathrm{~mm} \times 2.5 \mathrm{~m}\right.$, カラム温度 $100^{\circ} \mathrm{C}$, キャリヤーガ ス: $\left.\mathrm{H}_{2} 0.6 \mathrm{~kg} / \mathrm{cm}^{2}\right)$ 純度 $99 \%$ 以上のものを使用した。

4) J.W.Ward, J. Catal., 11, 251(1968).

5) P. J.Wilur, C. E. Mitchell, Solar Energy, 17, 193 (1975).

6) C.D.Chang, W. H. Lang, R. L.Smith, J. Catal., 56 , 169(1979)

7）野村正人, 堸田和人, 藤原義人, 日化，1989，475.

8) R. Criegge, P. Gunther, Chem. Ber., 96, 1564(1963).

9) K.Gollnick, G.O.Schenck, Pure Appl. Chem., 9, 507(1964).

10) A. Nikon, Perfemery Essent, Oil Record., 45, 149 (1956).

11）松原義治, 田中清文, 有合化，31，835(1973). 
[1]: bp $82 \sim 83^{\circ} \mathrm{C} / 25 \mathrm{mmHg}, \quad d_{4}^{25}=0.8361, \quad n_{\mathrm{D}}^{25}=1.4686$, $[\alpha]_{\mathrm{D}}^{30}=+96.7^{\circ}$

$\lceil 2\rfloor:$ bp $155 \sim 156^{\circ} \mathrm{C}, \quad d_{4}^{25}=0.8563, \quad n_{\mathrm{D}}^{25}=1.4652, \quad[\alpha]_{\mathrm{D}}^{30}=$ $+33.45^{\circ}$

[3] : bp 164 $165^{\circ} \mathrm{C}, \quad d_{4}^{25}=0.8621, \quad n_{\mathrm{D}}^{25}=1.4734, \quad[\alpha]_{\mathrm{D}}^{30}=$ $-19.55^{\circ}$

[4]: bp 157 $159^{\circ} \mathrm{C}, \quad$ mp 52 $53{ }^{\circ} \mathrm{C}, \quad d_{4}^{25}=0.8621, \quad n_{\mathrm{D}}^{25}=$ 1. 4734, $[\alpha]_{\mathrm{D}}^{30}=-49.55^{\circ}$

トリシクレン〔5]：純カンフェンを精留した際にトリシクレ ン留分（bp 152 153 ${ }^{\circ} \mathrm{C},[4] /[5]=26 / 74 ）$ をアルカリ性 $10 \%$ 過マンガン酸カリウム水溶液で酸化したのち, 常法ど打り操作し て得られる[5]を金属ナトリウム上に煮沸, 蒸留を絽り返し行 ったものを使用した（純度 $98 \%$ )。

bp $151 \sim 152^{\circ} \mathrm{C}, \mathrm{mp} 64 \sim 65^{\circ} \mathrm{C}$ 。

\section{2 合成ゼオライト}

表 1 に示した市販品（東ソ一株式会社製）の各種粉末ゼオライ トを使用した。

\section{3 実験方法（表 1 の実験番号 4 を例にあげる）}

温度計, 還流冷却器およびかきまぜ機を付した容量 $50 \mathrm{~m} l$ の四 つロフラスコに〔1] $0.015 \mathrm{~mol}(2 \mathrm{~g})$ と試料に対し 10 倍量の水 $(20 \mathrm{~g})$ をとり，かきまぜながら試料と同量の HSZ-710 HOA 合 成ぜオライトを加えたのち, 内温 $90 \sim 100{ }^{\circ} \mathrm{C} て ゙ 76$ 時間激しくか きまぜた。反応終了後, 合成ぜオライトを沪別したのち, 油分を へキサン抽出し, ついで $10 \%$ 炭酸ナトリウム水溶液, 水で処 理を行ったのち, 無水硫酸ナトリウムで乾燥後, 一キサンを留 去（湯浴上）し淡黄色の粗反応油を得た。反応油の GLC（PEG $600010 \%, 60 \sim 80$ メッシュ, 担体: セライト $545, \phi 3 \mathrm{~mm} \times$ $2.25 \mathrm{~m}$ ，カラム温度 $180^{\circ} \mathrm{C}$ ，キャリヤーガス: $\left.\mathrm{H}_{2} \quad 1.0 \mathrm{~kg} / \mathrm{cm}^{2}\right)$ には $p$-シメン [6]， $\alpha$-テルピネオール[7]，d-カルボン [8], trans-カルベオール〔9] および cis-カルベオール [10] ([6] : [7]:[8]: [10]=19:5.5:75.5: trace : trace) が認 められた。各成分は分取 GLC (PEG 20 M 25\%，60 80 ^ッ シュ, 担体: 七ライト $545, \phi 3 \mathrm{~mm} \times 2.25$, カラム温度 $160^{\circ} \mathrm{C}$, キャリヤーガス: $\mathrm{H}_{2} 0.6 \mathrm{~kg} / \mathrm{cm}^{2}$ ) とより単離し, 構造は IR（日 本分光株式会社製, IR-810型), ${ }^{1} \mathrm{H}-\mathrm{NMR}$ (日本電子株式会社製, MH-100 型) および GC-MS（日本電子株式会社製，JMS-QH 100)スペクトルを測定後, 文献と比較同定 ${ }^{12113)}$ し明らかにした。

Table 1 Properties of synthetic zeolites

\begin{tabular}{cccc} 
Zeolite & Type & Cation & $\begin{array}{c}\mathrm{SiO}_{2} / \mathrm{Al}_{2} \mathrm{O}_{3} \\
\text { molar ratio }\end{array}$ \\
\hline $5 \mathrm{~A}$ & $\mathrm{~A}$ & $\mathrm{Ca}$ & 2.02 \\
$13 \mathrm{X}$ & $\mathrm{X}$ & $\mathrm{Na}$ & 2.48 \\
$1010 \mathrm{AH}$ & Clinoptilolite & $\mathrm{H}$ & 13.83 \\
$2020 \mathrm{AH}$ & Mordenite & $\mathrm{H}$ & 10.74 \\
$\mathrm{HSZ}-320 \mathrm{CAA}$ & $\mathrm{Y}$ & $\mathrm{Ca}$ & 5.84 \\
HSZ-330 HUS & US-Y & $\mathrm{H}$ & 7.33 \\
HSZ-330 HSA & S-HY & $\mathrm{H}$ & 6.20 \\
HSZ-330 CAA & Y & $\mathrm{Ca}$ & 6.00 \\
HSZ-360 HUA & HS-USY & $\mathrm{H}$ & 14.10 \\
HSZ-620 HOA & Mordenite & $\mathrm{H}$ & 16.34 \\
HSZ-640 HOA & Mordenite & $\mathrm{H}$ & 18.90 \\
HSZ-710 HOA & Ferrierite & $\mathrm{H}$ & 18.08
\end{tabular}

12) U. R. Nayak, S. Dev, Tetrahedron, 8, 42(1960).
$2.4 \alpha$-テルピネオール $[\mathbf{7} \mathrm{a}], \boldsymbol{d}$-カルボン $[8]$ および transベルベノール [11] の合成単離

試料 [1]〜 [3] $10 \mathrm{~g}$ を用いて上記化合物が得られる最も高い 選択率の反応条件下で水和反応を行ったのち得られる反応油につ いて Jones 試薬 $\left(\mathrm{CrO}_{3}\right.$ : 濃 $\left.\mathrm{H}_{2} \mathrm{SO}_{4}: \mathrm{H}_{2} \mathrm{O}=4 \mathrm{~g}: 0.6 \mathrm{ml}: 5 \mathrm{ml}\right)$ による酸化反応を行った。その後, シリカゲルを充埧したガラス カラムクロマトグラフィー ${ }^{14)}$ により分画したのち，小形精密分留 塔を用いて減圧下に精留を行った結果，〔1]から〔8]を $1.8 \mathrm{~g}$ $\left([\alpha]_{D}^{25}=+58.5^{\circ}\right.$, 収率 $\left.16.1 \%\right)$ の収量で得た。〔2〕から [7a]を $4.2 \mathrm{~g}\left([\alpha]_{D}^{25}=72.6^{\circ}\right.$, 収率 $\left.37.1 \%\right)$ の収量で得た。ま た〔3]からは [11]を $4.8 \mathrm{~g}\left([\alpha]_{\mathrm{D}}^{25}=-42.8^{\circ}\right.$, 収率 $\left.42.3 \%\right)$ の収量で得た。

\section{3 結果および考察}

\section{$3.1 d$-リモネン〔1]の水和反応}

三置換オレフィン特よび末端メチレン基を有する「1]と水と の混合系による水和反応について, 表 1 亿示した各種ゼオライト を触媒として添加し, 反応生成物の選択性を追求した。表 2 亿ぜ オライトとの組及合わせによる比較的良好な反応条件を示す。ま た，反応油の GLC には 5 種の成分 [6]〜 10〕を確認すること ができた。

高シリカゼオライトで $\mathrm{SiO}_{2} / \mathrm{Al}_{2} \mathrm{O}_{3}$ のモル比が 18.8 でH型フ ェリェライトに属する HSZ-710 HOA 合成ゼオライトあるいは 鉱酸処理した天然ゼオライトで $\mathrm{SiO}_{2} / \mathrm{Al}_{2} \mathrm{O}_{3}$ 比が 13.83 でH型ク リノプチロライトに属する $1010 \mathrm{AH}$ ゼオライトを用いた条件 （Run 4 拈よび5）ではシクロへキセン環のアリル位が酸化され た $d$-カルボン [8]が主成分として, 生成物中 $72 \sim 76 \%$ の選択 率で得ることができた。

また， $\mathrm{Na}$ 型ゼオライトで $\mathrm{SiO}_{2} / \mathrm{Al}_{2} \mathrm{O}_{3}$ 比が 2.48 である $13 \mathrm{X}$ 合成ゼオライトを用いた反応条件（Run 2 打よび 3 ）では, ８８の前駆体としてその生成が考光られる trans-カルベオール [9]が副成分として得られ, 反応条件の一つである反応時間を延 ばすことにより, 反応油の転化率ならびに〔9]の生成比が增 加する傾向が認められた。また，得られた粗反応油をそれぞれ Jones 酸化することにより〔7〕と８８〕の 2 成分に集約するこ とができ，その反応油の GLC 組成比が 1：8から 2：3の割合 の組成比になることがわかった。このようなことから，反応使 用したゼオライトを回収し, 各ゼオライトの $\mathrm{SiO}_{2} / \mathrm{Al}_{2} \mathrm{O}_{3}$ 比を測定 したところ $5 \mathrm{~A}$ では $2.02 \rightarrow 1.95 ， 1010 \mathrm{AH}$ では 13.83 $\rightarrow 13.23$, $2020 \mathrm{AH}$ では $10.74 \rightarrow 10.43,13 \mathrm{X}$ では $2.48 \rightarrow 2.57, \mathrm{HSZ}-710$ HOA では $18.08 \rightarrow 17.75$ へと值が変化し, $13 \mathrm{X}$ ゼオライト以外 はいずれも $\mathrm{SiO}_{2} / \mathrm{Al}_{2} \mathrm{O}_{3}$ 比が低下し, その低下率は各ゼオライト によってそれぞれ異なり，この变化した值の差が実際に反応に関 与した $\mathrm{SiO}_{2} / \mathrm{Al}_{2} \mathrm{O}_{3}$ が持つ酸強度と酸量の消費された值であるも のと考光られる。この值から〔1〕の反応を考察すると, $\mathrm{SiO}_{2} /$ $\mathrm{Al}_{2} \mathrm{O}_{3}$ 比 10 以上の $1010 \mathrm{AH}$ あるいは HSZ-710 HOA を用いた

13) A.B. Booth, E. A. Klein, U.S.P., 2,803,659(1957).

14）和光純薬幣, $300 \times ッ シ ュ, 200 \mathrm{~g}$, カラム $(\phi 3.0 \times 80 \mathrm{~cm})$, 溶出液はへキサン，へキサン/眽酸エチル $(9.5: 0.5)$, へ キサン/クロロホルム $(9: 1)$, へキサン/クロロホルム $(8:$ 2), へキサン/メタノール (9:1), へキサン/メタノール (7:3), クロロホルムを順次用いた. 

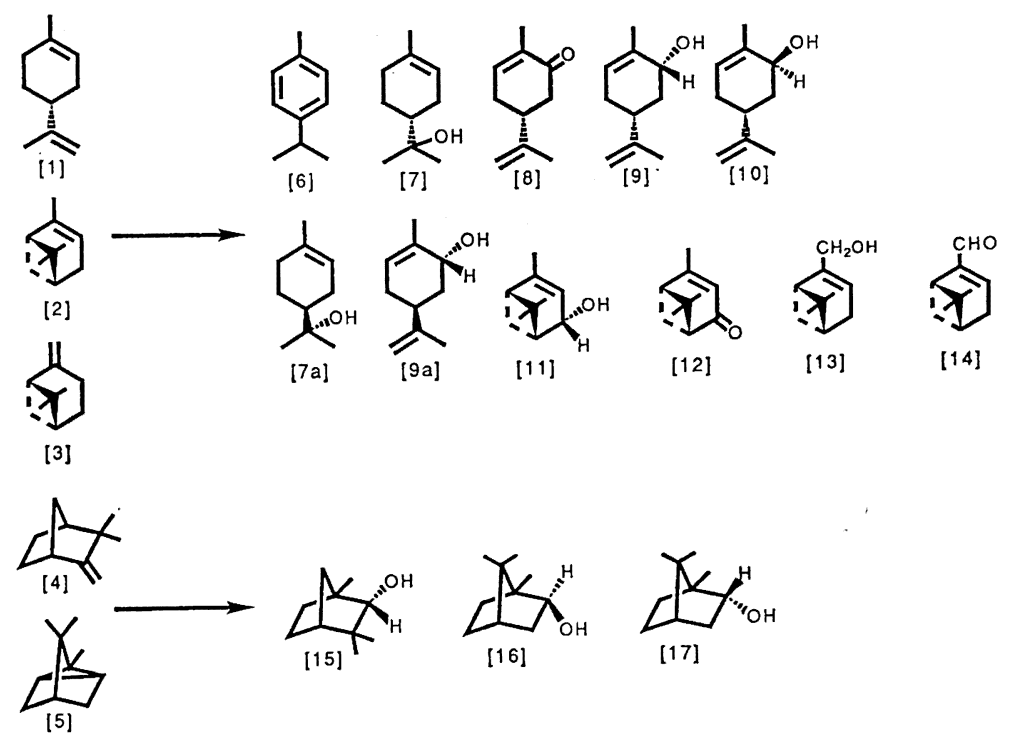

Fig. 1 Hydration products from [1], [2], $[3],[4]$ and $[5]$

Table 2 Reaction condition and the product composition from [1]

\begin{tabular}{|c|c|c|c|c|c|c|c|c|c|c|c|}
\hline \multirow[b]{2}{*}{ Run } & \multirow[b]{2}{*}{ Zeolite } & \multirow[b]{2}{*}{ Solvent } & \multirow{2}{*}{$\begin{array}{c}\text { Temp } \\
\left({ }^{\circ} \mathrm{C}\right)\end{array}$} & \multirow{2}{*}{$\begin{array}{l}\text { Time } \\
(\mathrm{h})\end{array}$} & \multirow{2}{*}{$\begin{array}{c}\text { Conv. } \\
(\%)\end{array}$} & \multicolumn{6}{|c|}{ Product composition ( $\%)$} \\
\hline & & & & & & [6] & {$[7]$} & [8] & {$[9]$} & {$[10]$} & Others $^{a)}$ \\
\hline 1 & $5 \mathrm{~A}$ & $\mathrm{H}_{2} \mathrm{O}$ & $90 \sim 100$ & 94 & 56 & Tr. & Tr. & 46 & 26 & 5 & 23 \\
\hline 3 & $13 \mathrm{X}$ & $\mathrm{H}_{2} \mathrm{O}$ & $90 \sim 100$ & 81 & 64 & $\operatorname{Tr}$. & 3 & 53 & 21 & 1 & 22 \\
\hline 4 & $\mathrm{HSZ}-710 \mathrm{HOA}$ & $\mathrm{H}_{2} \mathrm{O}$ & $90 \sim 100$ & 76 & 45 & 19 & 5.5 & 75.5 & Tr. & Tr. & Tr. \\
\hline 5 & $1010 \mathrm{AH}$ & $\mathrm{H}_{2} \mathrm{O}$ & 100 & 78 & 42 & 5 & 8 & 72 & 4 & 5 & 6 \\
\hline
\end{tabular}

a) Others consisted of several components.

Table 3 Reaction condition and the product composition from [2] and [3]

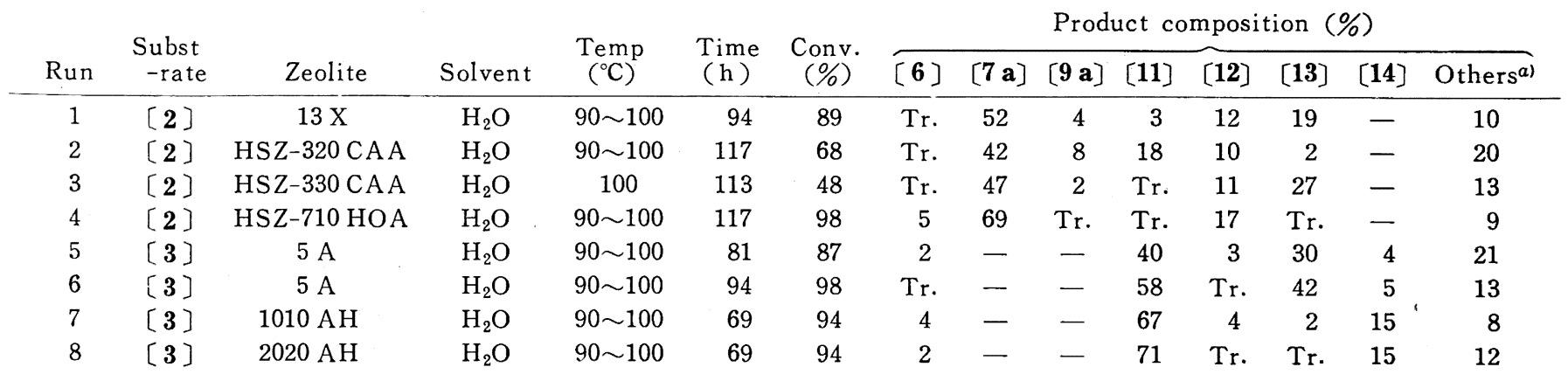

a) Others consisted of several components.

条件では, ケトン体である〔8]への高い選択性が認められた。 また, $\mathrm{SiO}_{2} / \mathrm{Al}_{2} \mathrm{O}_{3}$ 比が 5 以下の $5 \mathrm{~A}$ あるいは $13 \mathrm{X}$ を用いた条件 そ拈いてはアルコール体 [9] が生成しておうり，反応時間を延長 すると〔8]の生成割合が増加することなどから，〔1]の反応で はゼオライトの $\mathrm{SiO}_{2} / \mathrm{Al}_{2} \mathrm{O}_{3}$ 比を考虑することにより，目的化合 物を有利に得ることができるものと思われ，従来の酸を用いた水 和反応 ${ }^{15)}$ とは異なった結果を見いだすことができた。

3.2 2-ビネン〔2〕および 2(10)-ピネン〔3〕の水和反応

〔2〕扰よ゙〔3]についても 3.1 の項と同様汇, 種々のゼオ

15）松原義治, 田中清文, 浦田 貢, 福永敏雄, 桑田 勝, 高 橋敬, 日化, 1975, 855 .
ライトと水との混合系による水和反応について最適条件を検討し た。それぞれの反応条件および生成物の組成比を表 3 亿示す。 〔2〕の水和反応の場合, 主成分はいずれもピナン骨格が開裂し て得られる [7a] であり，その最適条件としては HSZ-710 HOA ゼオライトを用いた実験番号 4 の反応条件が良好であり，生成物 中 $69 \%$ の選択率で得ることができた。また，13X 合成でオライ 卜を用いた実験番号 1 の反応条件およびY型ゼオライトで $\mathrm{Ca}^{2+}$ 置換されている HSZ-330CAA 合成ぜオライトを用いた実験番 号 3 の反応条件では, 副成分であるミルテノール [13]が 20 30\% 近い生成比を占めることがわかった。また，いずれのぜオラ イトを用いた条件に打いても，ベルベノン〔12〕が 10〜20\%の 
Table 4 Reaction condition and the product composition from [4] and [5]

\begin{tabular}{|c|c|c|c|c|c|c|c|c|c|c|c|c|c|}
\hline \multirow[b]{2}{*}{ Run } & \multirow{2}{*}{$\begin{array}{l}\text { Subst } \\
\text {-rate }\end{array}$} & \multirow[b]{2}{*}{ Zeolite } & \multirow[b]{2}{*}{ Solvent } & \multirow{2}{*}{$\stackrel{\mathrm{M}}{(\mathrm{OH} / \mathrm{Cl})}$} & \multirow{2}{*}{$\begin{array}{c}\text { Temp } \\
\left({ }^{\circ} \mathrm{C}\right)\end{array}$} & \multirow{2}{*}{$\begin{array}{l}\text { Time } \\
\text { (h) }\end{array}$} & \multirow{2}{*}{$\begin{array}{c}\text { Conv. } \\
(\%)\end{array}$} & \multicolumn{6}{|c|}{ Product composition $(\%)$} \\
\hline & & & & & & & & $\overparen{\mathrm{Alc}^{a)}}$ & {$[15]$} & [16] & [17] & Others $^{b}$ & $\overline{\mathrm{Di}^{(c)}}$ \\
\hline 1 & {$[4]$} & HSZ-330 HUA & $\mathrm{H}_{2} \mathrm{O}$ & $\mathrm{ZnCl}_{2}$ & $90 \sim 100$ & 112 & 98 & 100 & Tr. & 35 & 54 & 11 & - \\
\hline 3 & {$[4]$} & $\mathrm{HSZ}-620 \mathrm{HOA}$ & $\mathrm{H}_{2} \mathrm{O}$ & $\mathrm{Ni}(\mathrm{OH})_{2}$ & $90 \sim 100$ & 115 & 40 & 100 & 12 & 74.5 & Tr. & 13.5 & - \\
\hline 4 & {$[4]$} & $\mathrm{HSZ}-620 \mathrm{HOA}$ & $\mathrm{H}_{2} \mathrm{O}$ & $\mathrm{CuCl}_{2}$ & $90 \sim 100$ & 112 & 87 & 100 & 4 & 80 & 6 & 10 & - \\
\hline 5 & {$[4]$} & $\mathrm{HSZ}-710 \mathrm{HOA}$ & $\mathrm{H}_{2} \mathrm{O}$ & - & $90 \sim 100$ & 51 & 50 & 100 & 12 & 58 & 15 & 15 & - \\
\hline 8 & {$[5]$} & $\mathrm{HSZ}-620 \mathrm{HOA}$ & $\mathrm{H}_{2} \mathrm{O}$ & $\mathrm{Al}(\mathrm{OH})_{3}$ & $90 \sim 100$ & 78 & 42 & 31 & 2 & 46 & 41 & 11 & 69 \\
\hline 9 & {$[5]$} & $\mathrm{HSZ}-640 \mathrm{HOA}$ & $\mathrm{H}_{2} \mathrm{O}$ & $\mathrm{Cu}(\mathrm{OH})_{2}$ & $90 \sim 100$ & 82 & 35 & 100 & - & 75 & 4 & 21 & - \\
\hline
\end{tabular}

a) Alcohols.

b) Others consisted of several components.

c) Dimer.

生成比で得られることから，これらの反応油を水素化りチウムア ルミニウムで還元することにより，松柏類を攻撃するキクイムシ の性フェロモンである〔11〕へ集約することができ興味ある結果 を見いだすことができた。つぎに，〔3]の水和反応ではとくに 型ゼオライトで $\mathrm{Ca}^{2+}$ が存在している $5 \mathrm{~A}$ 合成ゼオライトあるい は天然ゼオライトである $1010 \mathrm{AH}$ および $2020 \mathrm{AH}$ を用いた条 件（表 3）において良好な条件を見いだすことができ，いずれも 5 種の成分 [6]，[11]〜［14]を確認することがでさた。また，主 成分は〔11]であり，2020 AH を用いた条件（実験番号 8）にお いて, 反応後の $\mathrm{SiO}_{2} / \mathrm{Al}_{2} \mathrm{O}_{3}$ 比を測定すると 10.43 であり, ゼオ ライトの結晶構造が多少の変化にもかかわらず, 水和反応が生起 するのに適量な酸量になり, 最も高い選択率 (71\%) で目的物で ある[11]を得ることができた。また， $\mathrm{SiO}_{2} / \mathrm{Al}_{2} \mathrm{O}_{3}$ 比が 2 付近の $5 \mathrm{~A}$ ゼオライトを用いた条件では〔11]と〔13]の 2 成分の GLC 組成比が約 $3: 2$ の割合になることもわかった。これら実験番号 $5 ， 6$ の反応油を酸化 (Jones 試薬) あるいは還元 $\left(\mathrm{LiAlH}_{4}\right)$ す ることにより〔11]，〔13]あるいは〔12]，〔14]に集約すること も可能であり，ゼオライトを使い分けることにより従来の水和反 応 $^{16)}$ とは非常に異なった結果を見いだすことができた。

このように〔2]と〔3]の水和反応を比較すると, 使用する ゼオライトとの組み合せを考虑すると, 生成物に大さな相違が認 められ，〔2〕ではいずれのゼオライトを用いても環開裂が進行 し，とくに $\mathrm{Na}^{+}$あるいは $\mathrm{H}^{+}$タイプの高シリカゼオライトが反 応に最適であり, 異性化が起こりにくいゼオライトを用いた条件 では極端に目的物の酸化生成物の選択性が低下するなどの傾向 が認められた。すなわち, $\mathrm{H}^{+}$タイプで高シリカゼオライトの HSZ-710 HOA $\left(\mathrm{SiO}_{2} / \mathrm{Al}_{2} \mathrm{O}_{3}\right.$ 比=18.80) を用いた条件では, 転化 率 98\%，選択率 69\% で〔7a] が得られるのに対し, $\mathrm{Na}^{+}$タイ プでも $\mathrm{SiO}_{2} / \mathrm{Al}_{2} \mathrm{O}_{3}$ 比が 2 付近の $13 \mathrm{X}$ では骨格変化を伴わない [12]，〔13]が 10〜20\% で得られるなど選択性が低下する傾向に ある。また, $\mathrm{Ca}^{2+}$ タイプで $\mathrm{SiO}_{2} / \mathrm{Al}_{2} \mathrm{O}_{3}$ 比が 6 付近の $\mathrm{HSZ}-320$ CAA あるいは HSZ-330 CAA ゼオライトを用いた条件では, 転 化率ならびに選択率が HSZ-710 HOA にくらべて低い值を示す 結果が得られた。一方，[3]の反応では, $\mathrm{H}^{+}$タイプで $\mathrm{SiO}_{2} / \mathrm{Al}_{2}$ $\mathrm{O}_{3}$ 比が 10〜13 の領域のゼオライトを用いたにもかかわらず異

16）松原義治, 田中清文, 今城 広, 剣宝正美, 有合化, 31 , 475(1973).
性化は生起せず，〔11]を主生成物として得ることができた。す た, $\mathrm{Ca}^{2+}$ タイプで $\mathrm{SiO}_{2} / \mathrm{Al}_{2} \mathrm{O}_{3}$ 比が 2 付近の $5 \mathrm{~A}$ ゼオライトを用 いた条件では, 副生成物として末端ビニル基が酸化された〔13〕 が生成物中, $24 \sim 30 \%$ を占めたのに対し, 天然ゼオライトで鉱酸 処理した $1010 \mathrm{AH}\left(\mathrm{SiO}_{2} / \mathrm{Al}_{2} \mathrm{O}_{3}\right.$ 比=13.83）あるいは $2020 \mathrm{AH}$ $\left(\mathrm{SiO}_{2} / \mathrm{Al}_{2} \mathrm{O}_{3}\right.$ 比=10.74) ビオライトを用いた条件では, 酸化反応 がより進行しミルテナール〔14]が副生成物として得られるとと もに，〔11〕の選択性も向上する結果を見いだすことができた。し かし, $\mathrm{H}^{+}$タイプでも $\mathrm{SiO}_{2} / \mathrm{Al}_{2} \mathrm{O}_{3}$ 比が 15 以上の高シリカゼオラ イトを用いた場合には, 異性化が進行し, 目的生成物の選択性が 極端に低下寸ることもわかった。

\section{3 カンフェン〔4]およびトリシクレン［5]の水和反応}

[4]および〔5]の水-ゼオライト混合系の水和反応では [4]の HSZ-710 HOA 合成ゼオライトを用いた条件（実験番号 5）においてのみ反応が生起し，イソボルネオール〔16]が主成 分として得ることができた。そこで, 著者らはカチオン交換ゼオ ライトの酸性発現機構に着目し, 同一反応系内に金属水酸化物あ るいは金属塩化物を添加することにより，ゼオライトの固体酸性 を左右する酸点週辺の雾囲気を変えた水和反応を行った。その結 果, [4]の水和反応では高シリカゼオライトで US-Y 型（プロト ン）に属し, $\mathrm{SiO}_{2} / \mathrm{Al}_{2} \mathrm{O}_{3}$ 比が 5.9 の HSZ-330 HUA 合成ゼオラ イトに塩化亜鉛を添加した条件（実験番号 1) では, ヒドロキシ ル基の立体配置が exo 形の〔16〕の生成割合が押さえられる一 方, endo 形のボルネオール [17] の生成割合が $50 \%$ 以上を占め る結果が得られた。また, HSZ-330 HUA の反応系内にゼオライ トの構成成分である水酸化アルミニウム $\mathrm{Al}(\mathrm{OH})_{3}$ を存在させた 条件 (実験番号 2) では, $\mathrm{SiO}_{2} / \mathrm{Al}_{2} \mathrm{O}_{3}$ 比が従来の值よりも 4.08 と極端に小さくなると同時に, 酸強度も弱くなるなどの影響によ り, 水和よりも脱水素をともなら異性化により二量化が生起し, いまだ構造末決定（現在検討中）のカンフェンダイマー（bp $126 \sim 139^{\circ} \mathrm{C} / 2 \mathrm{mmHg}$ ）と思われる生成物を確認することができ た。また, $\mathrm{SiO}_{2} / \mathrm{Al}_{2} \mathrm{O}_{3}$ 比が 16.34 の HSZ-620 HOA 合成ゼオ ライトに水酸化ニッケルあるいは塩化銅（I）を添加した実験番 号 3，4 では従来の水和反応 ${ }^{17)}$ と同様，〔16〕が主成分として 得られた。このことは, 反応系内にニッケルイオン（交換率 9.48\%）あるいは銅イオン（交換率 9.44\%）が存在することによ

17）松原義治, 田中清文, 斉藤 嗣, 有合化, 31, 835(1973). 
り, $\mathrm{SiO}_{2} / \mathrm{Al}_{2} \mathrm{O}_{3}$ 比を測定すると 15.26 ならびに 14.9 の值が得ら れ，その比率が減少しているにもかかわらず，ゼオライトの酸点 周辺に金属カチオンが配置したような形態が考えられるなどの影 響により，ゼオライト自体がより活性化された状態になり，この よらな結果が得られたものと考穴られる。つぎに，[5]の水和反 応では HSZ-620 HOA 合成ゼオライトに水酸化アルミニウムを 添加した実験番号 8 ではダイ マー部の生成割合が大きい反面,

〔16]と〔17]の生成割合が皃 1：1になることもわかった。こ
のよ5に, 反応系内に助触媒としての金属水酸化物あるいは金属 塩化物を添加することにより金属カチオンがゼオライトの表面あ るいは細孔内に配置するなどにより結晶構造自体が変化すること が考觉られ，このような影響により触媒機能が高められたりある いは制御することなどができ，反応の場を変化させることが可能 となり，目的の反応生成物に選択性を持たせることができた。ま た, 本反応は, ゼオライトの固体酸触媒としての特徵が最もよく 生かせた反応の一つであるものと思われる。

\section{Hydration of Several Monoterpene Hydrocarbons with Water ${ }^{\dagger}$ in the Presence of Synthetic Zeolites ${ }^{\dagger}$ \\ Masato Nomura*, Yoshihito Fujihara, Hidekazu Takata* Takashi HiroKawA* and Akio Yamada** \\ Department of Industrial Chemistry, Faculty of Engineering, Kinki University; Takaya, Higashi-hiroshima-shi 729-17 Japan \\ ** Department of Industrial Chenistry, Fucuyry of Engineering, Kinki University; Kashinomori, Iizuka-shi 820 Japan}

Hydration of $d$-limonene [1], 2-pinene [2], 2(10)-pinene [3], camphene [4] and tricyclene [5] with water in the presence of synthetic zeolites was studied. The zeolite effects on the product distribution were examined. In the HSZ-710 HOA Zeolite, $d$-carvone [8] was obtained from [1] as a main product, amounting to more than $75.5 \%$ of the hydration products. Hydration of [2] gave $\alpha$-terpineol [ $7 \mathrm{a}]$ as a major product. In the $2020 \mathrm{AH}$ zeolite, trans-verbenol [11] was obtained from [3] as a main product, amounting to $71 \%$ of the hydration products under the optimal conditions. Hydration of [4] with $\mathrm{CuCl}_{2}$ in the presence of HSZ-620 HOA zeolite afforded predominantly isoborneol [16]. Under particular conditions, the [16]/n-borneol [17] ratio was $2: 3$ or $1: 1$. Hydration of [5] with $\mathrm{Cu}(\mathrm{OH})_{2}$ in the presence of $\mathrm{HSZ}-640 \mathrm{HOA}$ zeolite gave [16], as a main product.

$\dagger$ Studies on the Reaction of Terpenes in the Presence of Synthetic Zeolites. X. 